\title{
Monitoring of Air Pollution in the Area Affected by the Storage of Primary Oil Refining Waste
}

\author{
Alexey V. Strizhenok ${ }^{1 *}$, Andrey V. Ivanov ${ }^{1}$ \\ 1 Saint Petersburg Mining University, Vasilyevsky Island, 21st line 2, 199106, Saint-Petersburg, Russia \\ * Corresponding author's e-mail: alexeystrizhenok@mail.ru
}

\begin{abstract}
At present, monitoring of air pollution near industrial facilities is one of the most urgent tasks. Its implementation is a requirement of Article 42 of the Constitution of the Russian Federation and the basis for the ecological wellbeing of the population. This problem is especially critical for the production facilities located within residential areas or in close proximity to them. The scientific article presents the results of a monitoring study of the air pollution in a residential area exposed to the negative impact of the storage of primary oil refining waste. Within the frames of the scientific research, the analysis of the stock materials of the enterprise was conducted; field observation was performed on the territory of the considered enterprise and the construction of ecological cartographic models was carried out, reflecting the level of the air pollution in the territory under consideration. The study also carried out a literary review and presented a list of the main existing technologies for the utilization of oil sludge to improve the quality of the air in the region under consideration.
\end{abstract}

Keywords: environment, oil, oil sludge, sludge pond, air pollution, dispersion of pollutants in the atmosphere, environmental mapping.

\section{INTRODUCTION}

Presently, the oil industry is one of the most significant industries, and, therefore, one of the most dynamically developing [Pashkevich and Petrova 2016]. Today, it is impossible to imagine the life of a modern person without oil. All the main types of fuel, polymeric materials, synthetic fibers and even medicines are all oil refined products, without which human life would look completely different [Gaysina 2016].

Oil is one of the basic human needs today. Oil production and refining constitute one of the most significant sectors of the economy for some countries, providing a significant share of GDP. The purchase of oil and its products is a significant expenditure for other countries [Semyachkov et al. 2018]. Therefore, it can be said without exaggeration that oil and its refined products are one of the most profitable goods for the countries around the world nowadays.
At present, the oil industry is becoming one of the most dangerous industries for the environment as a result of an increase in oil production, transportation, processing and storage of oil products, as well as intensive development of technological solutions to increase oil recovery and the efficiency of all oil refining processes. All stages of production, transportation, processing and storage of oil and oil products have a colossal and long-term negative impact on all components of the natural environment, even with an accident-free operation [Gaysina 2016]. Emissions of significant volumes of pollutants into the atmosphere, deforestation and the removal of huge areas of the land fund from economic circulation, violation of the geological integrity of aquifers and pollution of surface and groundwater with oil products are just some examples of the impact of oil industry facilities on the environment. At the same time, accidental spills of oil and oil products can lead not only to the negative consequences for the 
territories where the oil industry facilities are located, but also to environmental disasters for all mankind [Pashkevich and Petrova 2016]. Despite this, the volumes of oil production and refining are growing annually, since the human need for oil products increases along with the growth of the population on the planet [Kuzhaeva and Dzhevaga 2017].

Presently, one of the least hazardous technological cycles in the oil industry is oil refining [Gaysina 2016]. However, along with high-tech equipment and low emergency hazard, the oil refining processes are accompanied by a significant negative impact on all components of the natural environment, including emissions into the atmosphere, pollution of surface waters and the formation of large amounts of waste. One of the most large-tonnage wastes of the oil refining process is oil sludge [Pashkevich and Petrova 2016].

Oil sludge is a complex physicochemical mixture, which consists of oil products, mechanical impurities (clay, metal oxides, sand) and water [Othman and Rahmat 2019]. More than 15 million tons of oil sludge is generated in the Russian Federation annually, about 12 million tons of which are formed in the process of hydrocarbon production and about 3 million tons in the process of preparation and primary processing of oil [Statistical collection 2018].

Oil sludge, in accordance with the Federal Classification Catalog of Waste of Russian Federation [Federal Classification Catalog] belongs to the 3rd hazard class, and the main method of its disposal today is storage in sludge ponds [State report about condition 2018]. Oil sludge has a significant negative effect on the air, being in operating or non-reclaimed sludge ponds, since the oil products evaporate from the surface of the sludge ponds at positive temperatures, and saturated hydrocarbons, hydrogen sulfide, benzene and xylene enter the air [Yuliarningsih et al. 2020]. In addition, the storage of oil sludge in sludge ponds makes it necessary for enterprises to allot a significant part of the territory of the enterprise for the placement of sludge ponds [Gaysina 2016].

This situation is especially critical for oil refineries, since the main refineries in Russia are located within the boundaries of settlements or in their immediate vicinity [State report about condition 2018], which limits the total territory of the enterprise, reduces the radius of the sanitary protection zone and increases the risk of adverse environmental situations in the residential area [Semyachkov et al. 2018].

In this regard, the main purpose of the research is to assess the negative impact of the oil sludge placed in sludge ponds on the territory of oil refineries on the air, as well as an overview of the modern methods of utilizing oil sludge to minimize the negative impact on the components of the natural environment and reduce the area of land removed from economic circulation.

\section{MATERIALS AND METHODS}

Scientific research was carried out on the example of one oil refinery in Russia, the activity of which is the preparation and primary processing of oil to obtain standard oil fractions - propanebutane, gasoline, kerosene, diesel, and fuel oil. The refinery capacity is 12 million tons of crude oil per year. The total area of the refinery is about 100 hectares, 4 of which about are occupied by oil sludge ponds [Nagornov and Kremcheeva 2017].

In order to achieve the aim of scientific research, the following tasks were implemented:

1. Research of stock materials of the enterprise and open sources in order to establish the amount of oil sludge accumulated in the sludge ponds for the entire period of operation of the enterprise, the amount of annually generated oil sludge, the chemical composition of the oil sludge, the climatic characteristics of the region in question, background air pollution and other characteristics on which the concentration of pollutants in the products of evaporation and their dispersion in the atmosphere depends;

2. Field observations on the territory of the oil refinery in order to establish the geometric characteristics of the sludge ponds, the degree of their protection from the external atmosphere (the presence of isolation of the surface of the sludge ponds), the presence of buildings and structures that form wind shadows;

3. Methodical calculations of the amount of pollutants entering the air during evaporation from the surface of sludge ponds, and computer modeling of the dispersion of these pollutants in the atmosphere, taking into account the influence of climatic characteristics, the degree of isolation of sludge ponds and buildings;

4. Literature review and patent search in order to form a list of recommended measures that can be applied at the considered production facility, 
to eliminate the oil sludge ponds and reduce the negative impact on the air of the region.

The main methods of scientific research were:

- system analysis of the enterprise stock materials and fundamental scientific works of Russian and foreign scientists on this topic;

- monitoring and landscape-geochemical studies in the field;

- methods of mathematical processing of the results of monitoring studies, modeling and forecasting of the state of natural and man-made complexes subject to anthropogenic load;

- methods of geoinformation ecological mapping.

The methodological calculations of the amount of pollutants entering the air during the oil sludge evaporation from the surface of the sludge ponds were carried out using the "RVU Ecolog" software product in accordance with the "Methodology for the Standardization and Determination of Hazardous Substances Emissions into the Atmosphere" [Methodology for the regulation 2004] and the "Methodological Guide for Calculation, Regulation and Control of Emissions of Pollutants into the Air" [Methodological manual for the calculation 2005].

The computer modeling of pollutants dispersion in the surface atmosphere and environmental mapping were carried out using the "UPRZA Ecolog" software product in accordance with the order of the Ministry of Natural Resources of the Russian Federation "On Approval of Methods for Calculating Dispersion of Hazardous (Pollutant) Substances in the Ambient Air" [Order of the Ministry of Natural Resources 2017].

\section{RESULTS AND DISCUSSION}

The following types of oil sludge are formed in the technological processes of the considered enterprise:

- reservoir oil sludge is formed during the storage of oil in reservoirs as a result of the physical and chemical interaction of oil products with the structural material. The composition of the waste is determined by the significant content of mechanical impurities (rust, metal shavings) and emulsified water;

- oil sludge from treatment facilities is formed during wastewater treatment and comes from the mechanical (oil trap) and physicochemical (flotation devices) treatment stages. The composition of oil sludge is determined by a significant amount of oil and water, as well as a high concentration of flocculants;

- oil sludge from recycling water supply units are formed during mechanical treatment (oil separators) of waste water used as recycling;

- ground oil sludge is formed during the collection of various spills of oil products and oils from the earth's surface. The content of mechanical impurities in such oil sludge reaches $80 \%$;

- oil sludge of tube bundles are formed during the cleaning of pipeline networks of refineries;

The oil sludge obtained at all stages of the technological process is disposed of in the sludge ponds located on the territory of the enterprise. Sludge collectors are earthen pits $50 \mathrm{~m}$ by $100 \mathrm{~m}$ with a depth of $4 \mathrm{~m}$, made in the form of a structure with a flat bottom using primary and secondary banking of fences. An image of the oil sludge ponds at the considered enterprise is shown in Figure 1. A waterproofing material for sludge ponds is a layer of rolled clay with a thickness of $0.8 \mathrm{~m}$, on the surface of which membrane geoflax is applied. This technology reliably prevents the ingress of oil products from sludge ponds into the soil and groundwater.

The main negative characteristic of the oil sludge ponds of the considered enterprise is their open surface, which is exposed to direct sunlight and precipitation, which leads to intensive evaporation of pollutants and a significant negative impact on the air of the region [Tsombueva 2014].

Field observations have shown that the oil sludge stratify, being in the sludge pond, as a result of which the main part of mechanical impurities settles on the bottom of the sludge pond, and its upper layer is similar in composition to oil, entered for primary processing. Evaporation of the light oil fractions occurs from the surface of sludge ponds under the constant influence of sunlight and positive average air temperatures typical for the area where the enterprise is located. The main pollutants, entered in atmosphere with the evaporation products, are methane hydrocarbons (alkanes) $-\mathrm{C}_{1}-\mathrm{C}_{12}$ [Hollingsworth et al. 2008]. Alkanes, especially those with a short carbon chain, have a narcotic and toxicological effect on living organisms. These hydrocarbons easily penetrate into the cells of organisms through 


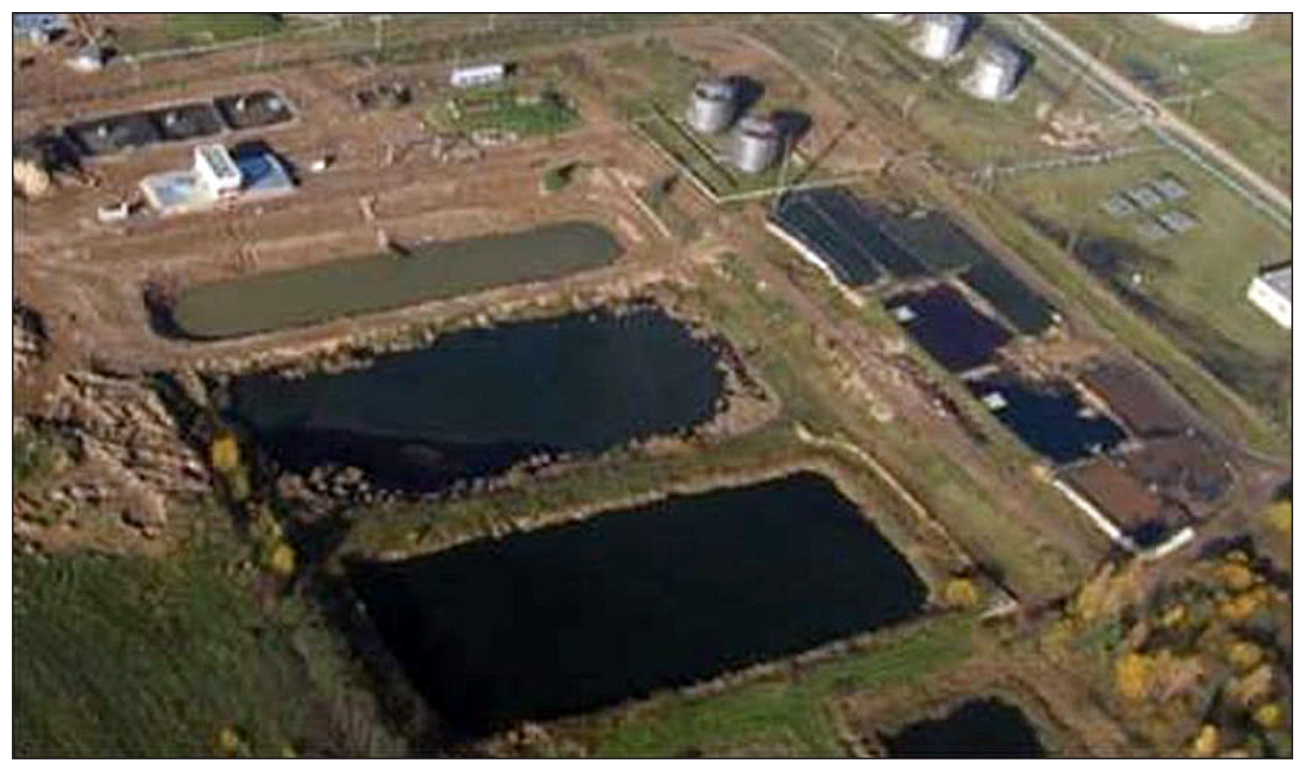

Figure 1. Image of oil sludge ponds at the considered enterprise

membranes, disorganizing the cytoplasmic organelles [Rhykerd et al. 1999].

The concentration of such hydrocarbons in the products of evaporation, as a rule, is not high; however, they activate the process of photochemical smog formation because of various oxidation mechanisms in air (for example, photolysis). Dangerous harmful substances are formed, such as formaldehyde, acrolein and others because of the reaction [Wang 2018].

The sulfur compounds (hydrogen sulfide) and aromatic hydrocarbons such as toluene, benzene and xylene are the most dangerous pollutants coming in significant volumes from the surface of sludge ponds.

Aromatic carbons mainly act on the central nervous system, causing damage. High concentrations of such compounds in the air can lead to acute and chronic poisoning, dizziness, headaches, anxiety, apathy, loss of consciousness and respiratory depression [Rhykerd et al. 1999].

The inhalation intake of hydrogen sulfide into the human body causes headache, dizziness and nausea, and leads to acute chronic poisoning. A high concentration of this substance in the air can cause convulsions, pulmonary edema, coma, and even death [Wang 2018].

It is important to note that oil sludge has a low capacity for accumulation, thereby causing minor damage to liver and heart cells [Hollingsworth et al. 2008].

Thus, the pollutants entering the air during evaporation from the open surface of sludge ponds directly affect the human body. Consequently, it is necessary to carry out systematic monitoring of the pollutants concentration in the air of the residential area located next to the oil sludge ponds.

The methodical calculations of the intensity of pollutants emission into the air during evaporation from the surface of the oil sludge ponds were carried out using the "RVU Ecolog" software product. This software package is aimed at calculating the intensity of the pollutants emission during various technological processes, including the emission from the open surfaces of oil sludge ponds and oil traps. The initial data are the climatic characteristics of the location region, the geometric characteristics of the sludge ponds, as well as the degree of cover of the sludge ponds surfaces.

The performed calculations showed that the main pollutants entering the air from the surface of oil sludge ponds are saturated hydrocarbons, hydrogen sulfide, benzene and xylene. At the same time, the total emissions of pollutants from the territory of all sludge collectors are significant. The results of calculating the intensity of the pollutants emission from the surface of oil sludge ponds are shown in Table 1.

The calculation of the total amount of pollutants released into the air from the open surfaces of the oil sludge ponds was carried out to confirm the reliability of the data obtained from the results of the "RVU Ecolog" program calculation. The calculation is based on the empirical dependence of the specific intensity of oil evaporation on the air temperature, shown in Figure 2 [Haustov and Redina 2006]. 
Table 1. The results of calculating the intensity of emission of pollutants from the surface of oil sludge ponds

\begin{tabular}{|l|c|c|}
\hline \multicolumn{1}{|c|}{ Contaminant } & $\begin{array}{c}\text { Intensity of pollutants emission, } \\
\text { g/second }\end{array}$ & $\begin{array}{c}\text { Total pollutants emission, } \\
\text { t/year }\end{array}$ \\
\hline Saturated hydrocarbons $\mathrm{C}_{1}-\mathrm{C}_{5}$ & 17.45 & 550.2 \\
\hline Saturated hydrocarbons $\mathrm{C}_{6}-\mathrm{C}_{10}$ & 19.69 & 620.9 \\
\hline Hydrogen sulfide & 0.054 & 1.7 \\
\hline Benzene & 1.28 & 40.3 \\
\hline Xylene & 0.77 & 24.3 \\
\hline
\end{tabular}

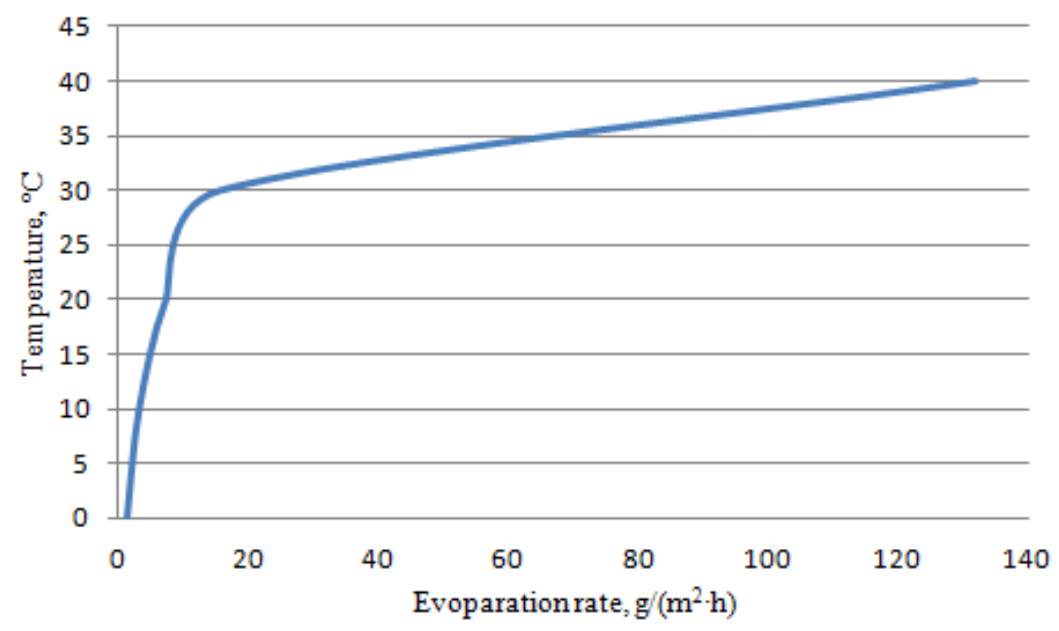

Figure 2. Empirical dependence of the specific intensity of oil evaporation on the air temperature

The initial data in the calculation are the total area of oil sludge ponds at the considered enterprise and the climatic characteristics of the region. The total amount of pollutants released the air during oil evaporation was obtained as a result of the calculation. The obtained value of the amount of pollutants (1241.7 t/year) correlates with the results of the methodological program calculations of the intensity of pollutants emission into the air from the surface of oil sludge ponds, which confirms the reliability of these results.

The calculation of the dispersion of pollutants in the air was performed based on the obtained results using the "UPRZA Ecolog" software product. The result of this calculation constitutes the cartographic models that reflect the spread of pollutants in the air and reflect the level of air pollution in the area under consideration. The resulting cartographic models of air pollution by emissions from the surface of oil sludge ponds are shown in Figure 3.

The contrast ratio, which is calculated as the ratio of the current concentration of the considered pollutant in the atmospheric air to the established standard, is adopted as a parameter for constructing isolines on the map. That is, all values greater than 1 show how many times the current concentration of the desired pollutant exceeds the established standard.

The cartographic model shown in Figure 1(f) is built based on the total pollution coefficient, which is the sum of the contrast ratio of all pollutants reflected in Table 1. Thus, this map reflects the complex negative impact on the atmosphere of the considered region in the result of pollutants evaporation from the surface of the oil sludge ponds.

The cartographic models presented in Figures 1(a) - 1(f) show that the regulatory concentration for the substances presented in Table 1 is exceeded from 1.5 to 10 times in the entire residential area, next to which the considered enterprise is located.

Thus, it is possible to speak with a high degree of accuracy about the significant negative impact of the oil sludge ponds on the air of the region, because of which an unfavorable ecological situation is formed in this territory.

The solution to this problem can be the isolation of the oil sludge ponds in order to minimize the contact of their surface with the atmosphere [Chen 2019]. However, in this case, the issue of minimizing the negative impact of the operating oil sludge ponds, as well as the need to remove 


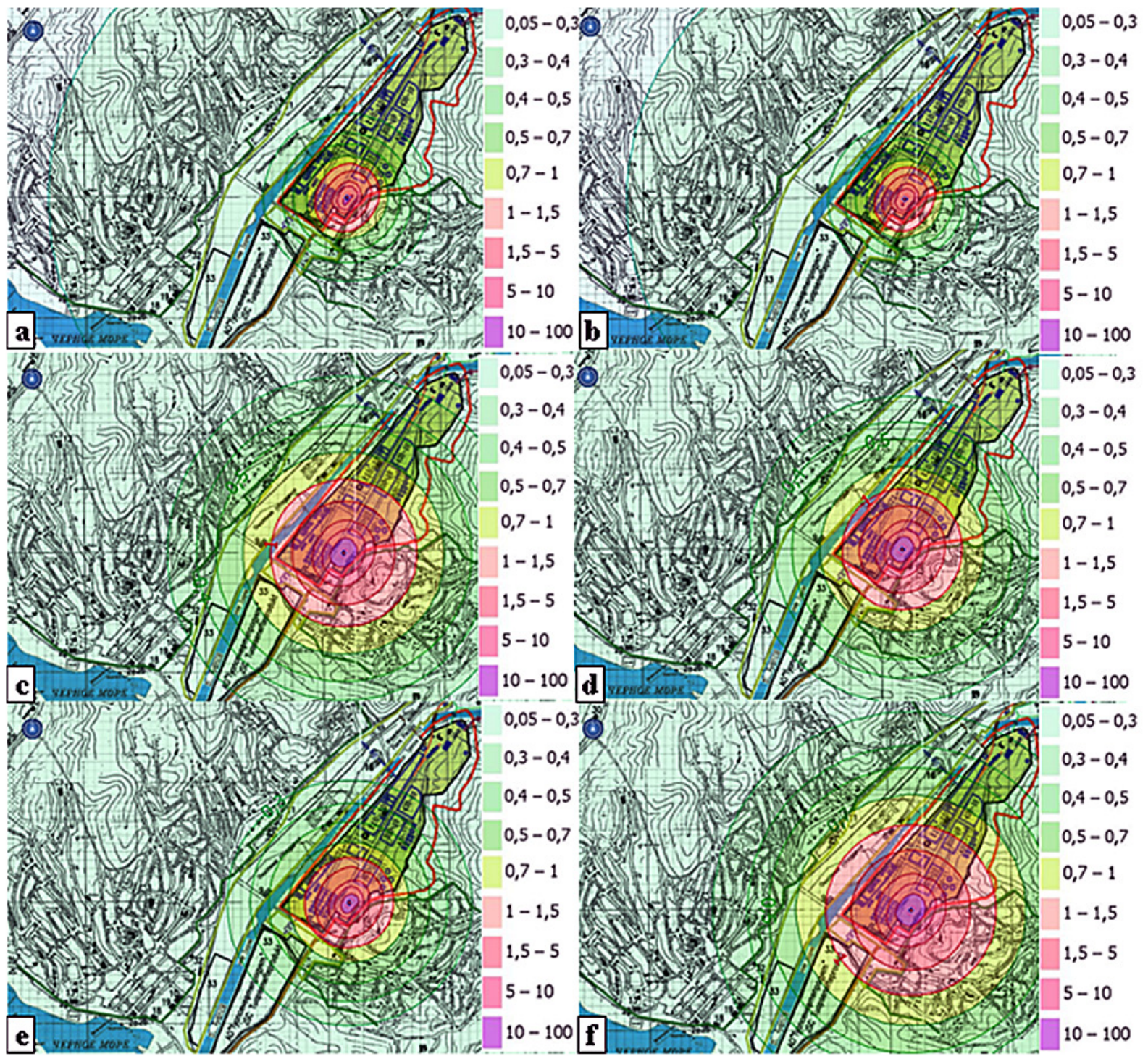

Figure 3. Cartographic models of air pollution by emissions from the surface of oil sludge ponds. $\mathrm{a}$ - saturated hydrocarbons $\mathrm{C}_{1}-\mathrm{C}_{5}, \mathrm{~b}$ - saturated hydrocarbons $\mathrm{C}_{6}-\mathrm{C}_{10}, \mathrm{c}$ - hydrogen sulfide, $\mathrm{d}$ - benzene, $\mathrm{e}$ - xylene, $\mathrm{f}$ - all pollutants

additional territories from economic circulation on the territory of placement of new oil sludge tanks [Pashkevich et al. 2019]. Thus, it can be assumed that the most expedient way to reduce the negative impact of the sludge ponds on the atmosphere and return the territory of the sludge ponds to economic circulation is the disposal of the stored and newly formed oil sludge and the reclamation of the sludge ponds [O'Brien et al. 2017].

In this regard, the authors carried out a literary review and formed a list of the main methods for the utilization of oil sludge, the most appropriate for implementation at the considered enterprise, taking into account the technical, economic, environmental and climatic characteristics, as well as shown the main advantages and disadvantages of the methods presented. The list of the main methods of oil sludge utilization and their characteristics is given in Table 2 [Othman and Rahmat 2019, Yuliarningsih et al. 2020, Rhykerd et al. 1999, Wang 2018, Haustov and Redina 2006].

\section{CONCLUSIONS}

The scientific research carried out by the authors allows drawing the following conclusions:

1. It was found that the total area of the oil sludge ponds at the considered enterprise is about 4 hectares. The sludge ponds are in the open air, 
Table 2. The main methods of oil sludge utilization and their characteristics

\begin{tabular}{|c|c|c|c|c|}
\hline Method & Variety & Process & Advantages & Disadvantages \\
\hline \multirow{2}{*}{ Thermal } & Burning in furnaces & $\begin{array}{l}\text { The process takes place at } \mathrm{t}= \\
800-1200^{\circ} \mathrm{C} \text { and excess oxygen. } \\
\text { Chamber, bubbler, shaft, fluidized } \\
\text { bed and rotary furnaces are used }\end{array}$ & $\begin{array}{l}\text { Relatively low capital costs, } \\
\text { simple design, finished } \\
\text { products - ash, high } \\
\text { productivity, widespread }\end{array}$ & $\begin{array}{l}\text { Requires multi-stage } \\
\text { waste gas cleaning }\end{array}$ \\
\hline & Pyrolysis & $\begin{array}{l}\text { The process takes place at } \mathrm{t}= \\
600-800-1200^{\circ} \mathrm{C} \text { in an anaerobic } \\
\text { environment }\end{array}$ & $\begin{array}{l}\text { Environmentally friendly } \\
\text { process, obtaining finished } \\
\text { products - liquid pyrolysis } \\
\text { fuel, reuse of pyrolysis gas }\end{array}$ & $\begin{array}{l}\text { High capital costs, low } \\
\text { plant productivity }\end{array}$ \\
\hline \multirow[t]{2}{*}{ Physical } & $\begin{array}{l}\text { Separation of waste } \\
\text { in a centrifugal field }\end{array}$ & $\begin{array}{l}\text { The process is based on the } \\
\text { separation of oil sludge into its } \\
\text { constituent components under } \\
\text { the action of centrifugal forces. } \\
\text { Centrifuges, tricanters and } \\
\text { separators are used }\end{array}$ & $\begin{array}{l}\text { Compactness, the } \\
\text { possibility of full } \\
\text { automation, favorable } \\
\text { sanitary conditions }\end{array}$ & $\begin{array}{l}\text { Labor intensity of the } \\
\text { subsequent disposal of } \\
\text { final products }\end{array}$ \\
\hline & Upholding & $\begin{array}{l}\text { The process is based on the } \\
\text { separation of oil sludge into its } \\
\text { constituent components as a result } \\
\text { of the difference in their densities }\end{array}$ & Simplicity of design & $\begin{array}{l}\text { Low speed, low } \\
\text { efficiency, requires large } \\
\text { settling areas }\end{array}$ \\
\hline Chemical & $\begin{array}{l}\text { Hardening by } \\
\text { dispersion with } \\
\text { reagents }\end{array}$ & $\begin{array}{l}\text { The process is based on the } \\
\text { use of solvents for dispersing } \\
\text { oil sludge (low-boiling paraffinic } \\
\text { hydrocarbons, a wide fraction } \\
\text { of light hydrocarbons, gas } \\
\text { condensate) }\end{array}$ & $\begin{array}{l}\text { High efficiency of the } \\
\text { recycling process }\end{array}$ & $\begin{array}{l}\text { High capital costs, } \\
\text { requires a significant } \\
\text { amount of solvent }\end{array}$ \\
\hline Biological & Biodegradation & $\begin{array}{l}\text { The process is based on the ability } \\
\text { of oil-oxidizing microorganisms to } \\
\text { degrade oil products }\end{array}$ & $\begin{array}{l}\text { Simple hardware design, } \\
\text { low capital costs }\end{array}$ & $\begin{array}{l}\text { Low productivity of the } \\
\text { process, impossibility } \\
\text { of operation at low } \\
\text { temperatures, low } \\
\text { efficiency at high } \\
\text { concentrations of oil } \\
\text { products }\end{array}$ \\
\hline \multirow[b]{2}{*}{$\begin{array}{l}\text { Physical- } \\
\text { chemical }\end{array}$} & $\begin{array}{l}\text { Flotation with } \\
\text { collection of oil } \\
\text { products by a drum } \\
\text { separator }\end{array}$ & $\begin{array}{l}\text { The process is based on the } \\
\text { neutralization of oil sludge by } \\
\text { means of hot water flotation } \\
\text { treatment }\end{array}$ & $\begin{array}{l}\text { Relatively low capital costs, } \\
\text { ensuring environmental } \\
\text { safety }\end{array}$ & $\begin{array}{l}\text { High cost of reagents, } \\
\text { formation of a large } \\
\text { amount of solid waste }\end{array}$ \\
\hline & Extraction & $\begin{array}{l}\text { The process is based on the } \\
\text { mutual dissolution of polar } \\
\text { compounds (oil products and } \\
\text { solvent) }\end{array}$ & $\begin{array}{l}\text { High efficiency of the } \\
\text { recycling process }\end{array}$ & $\begin{array}{l}\text { Significant loss of } \\
\text { solvent, the need to } \\
\text { remove the solvent } \\
\text { from the residue, high } \\
\text { capital costs for filter } \\
\text { regeneration }\end{array}$ \\
\hline
\end{tabular}

the surface insulation of the sludge ponds is not provided. Oil sludge stratifications into components occur because of the long-term presence in the sludge ponds, so the surface of the sludge pond is represented by almost crude oil, which intensifies the evaporation process.

2. Methodological calculations show that the main components entering the atmospheric air during the evaporation of oil from the surface of the oil sludge ponds are saturated hydrocarbons, hydrogen sulfide, benzene and xylene, while the emission intensity under these climatic conditions is $37 \mathrm{~g} / \mathrm{s}, 0.06 \mathrm{~g} / \mathrm{s}, 1.3 \mathrm{~g} / \mathrm{s}$ and $0.8 \mathrm{~g} / \mathrm{s}$, respectively.

3. Cartographic models were built, reflecting the spread of pollutants in the atmosphere and the quality of the air in the residential area. On the basis of the constructed models, it can be argued that in the entire residential area, next to which the production facility under consideration is located, there is an excess of the regulatory concentration for the main substances from 1.5 to 10 times.

4. On the basis of the obtained results, it was assumed that the most expedient way to reduce the negative impact of sludge ponds on the atmosphere and return the territories occupied by the sludge ponds to economic circulation is to utilize the stored and newly formed oil sludge and recultivate the sludge ponds territory. In this regard, the authors have compiled a list of the main methods for the disposal of oil sludge, the most appropriate for implementation at the considered production facility, taking into account the technical, economic, environmental and climatic characteristics. 


\section{Acknowledgement}

This scientific work is supported by the Scholarship of the President of the Russian Federation SP-3455.2019.3.

\section{REFERENCES}

1. Chen P. 2019. Visualization of real-time monitoring datagraphic of urban environmental quality. Eurasip Journal on Image and Video Processing, 2019(1), 42-51.

2. Federal Classification Catalog of Waste of Russian Federation. URL: http://kod-fkko.ru/ (21.09.2020).

3. Gaysina D.R. 2016. Analysis of the causes of emergency situations on trunk pipelines. Bulletin of Kazan Technological University, 19(14), 129-130.

4. Haustov A. P., Redina M.M. 2006. Environmental protection in oil production, pp. 551.

5. Hollingsworth A., Engelen R.J., Textor C., Benedetti A., Boucher O. 2008. Toward a monitoring and forecasting system for the atmospheric composition: the GEMS project. Bulletin of the American Meteorological Society, 89(8), 1151-1164.

6. Kuzhaeva A., Dzhevaga N. 2017. Particulars of oil structural organization. ARPN Journal of Engineering and Applied Sciences, 12(13), 4157-4166.

7. Methodological manual for the calculation, regulation and control of emissions of pollutants into the air, 2005.

8. Methodology for the regulation and determination of emissions of harmful substances into the atmosphere, 2004.

9. Nagornov D.O., Kremcheeva D.A. 2017. Assessment of gravity component of moisture flow in raw peat in conditions of convective and radiative-convective heat input. Journal of Industrial Pollution Control, 33(1), 749-752.

10. O'Brien P.L., DeSutter T.M., Ritter S.S., Casey F.X.M., Wick A.F., Khan E., Matthees H.L. 2017. A large-scale soil-mixing process for reclamation of heavily disturbed soils. Ecological Engineering, 109, 84-91.

11. Othman U.M., Rahmat M.N. 2019. Utilization Oil
Based Industrial Sludge as Potential Construction Components. IOP Conference Series: Materials Science and Engineering, 620(1), Article No. 012074.

12. Order of the Ministry of Natural Resources of the Russian Federation of 06.06.2017 No.273 “On the approval of methods for calculating the dispersion of emissions of harmful (polluting) substances in the air", 2017.

13. Pashkevich M.A., Petrova T.A. 2016. Creation of a system for industrial environmental monitoring in hydrocarbon production and transporting companies of Western Siberia. Journal of Mining Institute, 221, 737-741.

14. Pashkevich M.A., Petrova T.A., Rudzisha E. 2019. Lignin Sludge Application for Forest Land Reclamation: Feasibility Assessment. Journal of Mining Institute, 235, 106-112.

15. Rhykerd R.L., Crews B., McInnes K.J., Weaver R.W. 1999. Impact of bulking agents, forced aeration, and tillage on remediation of oil-contaminated soil. Bioresource Technology, 67(3), 279-285.

16. Semyachkov A.I., Slawikowskaja Y.O., Pochechun V.A. 2018. Methodological features of the assessment of economic damage from adverse environmental consequences in conditions of territories with a developed mining complex. Ecology and Industry of Russia, 22(4), 46-51.

17. State report about condition and protection of the environment of the Russian Federation in 2018. URL: http://gosdoklad-ecology.ru/2018/\%20 (21.09.2020).

18. Statistical collection "Environmental protection in Russia”, 2018, pp. 125.

19. Tsombueva B.V. 2014. The use of natural materials as sorbents for cleaning soils from oil pollution. Modern problems of science and education, 6, 1-7

20. Wang Y. 2018. Research and application of oil sludge resource utilization technology in oil field. IOP Conference Series: Earth and Environmental Science, 170(3), Article No. 0320262018.

21. Yuliarningsih R., Goembira F., Komala P.S., Putra N.P., Nasra M. 2020. Oil Sludge and Biomass Waste Utilization as Densified Refuse-Derived Fuels for Alternative Fuels: Case Study of an Indonesia Cement Plant. Journal of Hazardous, Toxic, and Radioactive Waste, 24(4), Article No. 05020001. 